Research Articles

\title{
Obstetric and Perinatal Characteristics of Teenage Pregnancies: an Analysis of Five Year Period in dr. Cipto Mangunkusumo Hospital, Jakarta
}

\author{
Junita Indarti, David E. Prasetya, Hari Sandi, Imam Rahmadi, Raymond Surya \\ Department of Obstetrics \& Gynecology, Faculty of Medicine, Universitas Indonesia \\ - dr. Cipto Mangunkusumo Hospital, Jakarta \\ *Corresponding author: junita_indarti@yahoo.com \\ Received 30 March 2020; Accepted 19 March 2021 \\ DOI: 10.23886/ejki.9.6.
}

\begin{abstract}
Teenage pregnancy leads to higher rates of maternal and perinatal complication and has been a major challenge globally. This study aims to evaluate the obstetric and perinatal characteristics of teenage pregnancies in Indonesian population. A cross-sectional study through medical records was performed at tertiary cared dr. Cipto Mangunkusumo Hospital, Jakarta, from 2014 to 2018. We recruited average maternal age of women and teenagers who carried singleton live pregnancies and delivered at tertiary care. Obstetrical complications include anemia at labor, preeclampsia/eclampsia, postpartum hemorrhage, preterm rupture of membrane, induction of labor, cesarean section delivery and perinatal outcomes include small-for-gestational age, stillbirth, intrauterine growth restriction, preterm birth, low birth weight, $5^{\text {th }}$ minimum APGAR score were assessed. Statistical analysis was done using SPSS 20. There were 4265 eligible subjects during 5-year period. The prevalence of teenage pregnancy (11-19 years old) was 543/4265 (12.7\%). Teenage pregnancy had a higher incidence of preterm deliveries (OR 2.047, 95\% Cl 1.660-2.524, $p \leq 0.001)$ and anemia at labor (OR 1.433, 95\% Cl 1.113-1.843, $p=0.005)$. Low birth weight babies (OR 1.520, 95\%Cl 1.229-1.879, $p \leq 0.01)$ were associated with teenage pregnancy. Teenage pregnancy contributes to higher incidence of preterm deliveries, anemia at labor, and low birth weight.
\end{abstract}

Keywords: teenage, pregnancy, outcome, maternal, perinatal.

\section{Karakteristik Obstetrik dan Perinatal pada Kehamilan Remaja: Analisis Lima Tahun di RSUPN Dr. Cipto Mangunkusumo, Jakarta}

\begin{abstract}
Abstrak
Kehamilan remaja meningkatkan komplikasi maternal dan perinatal serta merupakan tantangan global. Studi ini bertujuan untuk mengevaluasi karakteristik obstetrik dan perinatal kehamilan remaja di Indonesia. Studi potong lintang melalui rekam medis dilakukan di RSCM, Jakarta, pada tahun 2014 hingga 2018. Kriteria inklusi ialah kehamilan remaja dan usia reproduksi pasien yang melahirkan di RSCM. Komplikasi obstetrik yang dinilai adalah anemia saat persalinan, preeklamsia/eklamsia, perdarahan pascasalin, ketuban pecah dini, induksi persalinan, seksio sesarea, dan luaran perinatal yaitu janin kecil, lahir mati, pertumbuhan janin terhambat, persalinan prematur, berat lahir rendah, dan skor APGAR 5 menit. Analisis statistik menggunakan SPSS 20. Terdapat 4265 subjek selama 5 tahun dengan prevalensi kehamilan remaja (11-19 tahun) 543/4265 $(12,7 \%)$. Kehamilan remaja meningkatkan insidens persalinan prematur yang lebih tinggi (OR 2,047, 95\% Cl 1,660-2,524, $p \leq 0,001$ ) dan anemia saat persalinan (OR 1,433, 95\% Cl 1,113-1,843, $p=0,005)$. Berat badan lahir rendah berhubungan dengan kehamilan remaja (OR 1,520, 95\% Cl 1,229-1,879, $p \leq 0,01$ ). Kehamilan remaja memiliki dampak lebih tinggi terhadap persalinan prematur, anemia saat persalinan, dan berat lahir rendah.

Kata kunci: remaja, kehamilan, Iuaran, maternal, perinatal.
\end{abstract}




\section{Introduction}

Teenage pregnancy has been a major challenge globally. About 16 million women under the age of 20 gave birth each year worldwide, approximately 6 million teenagers in South East Asia. In Indonesia, it is estimated that there are more than 2 million teenage girls aged $15-19$ years old had given birth, which is around $10 \%$ of total births. ${ }^{1}$

There are multiple risk factors arise in teenage pregnancy, such as socioeconomic factors and low level of education. ${ }^{2}$ It is also reported that the risk of pregnancy in teenager is higher in developing countries, which are probably associated with poor health habits. Problems associated with teenage pregnancy are well documented such as poor maternal and neonatal outcomes. These poor outcomes cannot be explained by biologic barriers among teenagers and not solely to maternal young age, but they probably reflect poor health habits and high nutritional requirements. , $^{3,4}$

Available studies revealed that teenage pregnancy led to higher rates of low birth weight (LBW), preterm delivery, infections, stillbirth, neonatal mortality, and higher risk of developing congenital malformations. Higher admission rates to neonatal intensive care unit have also been reported. However, younger age of childbearing has consistently shown lower rates of gestational diabetes, cesarean section (CS) and instrumental delivery, with lower risk of complications associated with assisted births. ${ }^{2,3,5}$

A retrospective study evaluating obstetric and perinatal outcomes among teenage and average maternal age women in Indonesia revealed that teenage pregnancy was associated with higher prevalence of eclampsia, preterm delivery, anemia at labor, post-partum hemorrhage, and LBW, with significantly lower rates of CS. ${ }^{3}$ A similar cohort study in England also revealed similar outcomes, suggesting that young women might compete with the fetus for nutrients; therefore, fetal growth impairment would produce LBW babies or babies who were small-for-gestational age (SGA). ${ }^{5}$

Given both poor maternal and perinatal outcomes in teenage pregnancy, a proper management and intervention should be arranged. High quality antenatal care and education on health habits should be given. Apart from the health implications, teenage pregnancy may affect one's quality of life. This study aims to evaluate the five-year obstetric and perinatal characteristics of pregnancies during adolescence in dr. Cipto Mangunkusumo Hospital (Rumah Sakit dr. Cipto Mangunkusumo/RSCM), Jakarta, as a tertiary university referral hospital in Indonesia.

\section{Methods}

A cross sectional study was conducted from medical records recruiting women who carried singleton live pregnancies and gave birth in RSCM during the year of 2014-2018. Pregnant women were divided as average maternal age (AMA) women (20-34 years old) and teenagers (11-19 years old). Preterm birth is defined as pregnancy completion before 37 weeks' gestation. The maternal anemia is based on the Centers for Disease Control criteria, with a cut-off value of $11 \mathrm{mg} / \mathrm{dl}$ for hemoglobin. Preeclampsia is established when they have systolic blood pressure $\geq 140 \mathrm{mmHg}$ or diastolic blood pressure $\geq 90 \mathrm{mmHg}$ on two occasions 6 hours apart, and proteinuria $\geq 300 \mathrm{mg}$ per 24 hours or positive $(+)$ using dipstick test. Severe pre-eclampsia is defined as systolic blood pressure $>160 \mathrm{mmHg}$ or diastolic blood pressure $>110 \mathrm{mmHg}$ measured at least twice 6 hours apart, proteinuria $>5000 \mathrm{mg}$ per 24 hours or $\geq++$ using dipstick test, platelet count persistently $<100,000 / \mathrm{mm}^{3}$, serum transaminases more than twice normal. Eclampsia is established if seizure occur during gestation period among preeclampsia patients. Preterm rupture of membrane (PROM) refers to a patient who is beyond 37 weeks' gestation and has presented with rupture of membrane (ROM) prior to the onset of labor. SGA is defined as below $10^{\text {th }}$ percentile for completed week of gestational age based on the local percentile standards. The percentile of each neonates' birth weight was obtained from WHO global reference for fetal/birth weight percentiles calculator. ${ }^{1}$ LBW defined by birth weight below $2500 \mathrm{~g}$. Intrauterine growth restriction (IUGR) defines as SGA fetus with any sign of doppler measurement abnormality defined by the obstetrician. Post-partum hemorrhage is defined by bleeding more than $500 \mathrm{cc}$ (vaginal delivery), or more than $1000 \mathrm{cc}$ (CS), or by the clinical judgement of the physician if they find post-partum excessive bleeding that can be caused by either tone, tears, tissue, or thrombin problems. Induction of labor is usually performed with the use of doses of 25 mcg prostaglandin E1 (PGE1) tablets, received 6 hours apart. Oxytocin is injected when the cervix has fully ripen, at a basal infusion rate of $4 \mathrm{mIU} /$ min and increased $1 \mathrm{mlU} / \mathrm{min}$ every 20 minute until it produces 4-5 uterine contractions every $10 \mathrm{~min}$. The maximum applied dose is $20 \mathrm{mlU} / \mathrm{min}$.

Statistical analysis was performed using SPSS 20. Chi-square test was used for dichotomous variables. Fisher's exact test was applied wherever the number of observations was lower than five. The independent samples t-test was used for analysis 
of continuous variables with normal distribution, the Mann-Whitney test was used for analysis of continuous variables with non-normal distribution. The level of significance was set to $p<0.05$. Multiple logistic regression (enter method) was performed in order to assess the independent effect of being pregnant at adolescence on specific indicators of morbidities with significant difference.

\section{Results}

A total of 4265 pregnancies were studied during January 2014 to December 2018. Of all subjects,
$3722(87.3 \%)$ pregnant women were classified in AMA group (20-34 years old) and $543(12.7 \%)$ teenage mothers were in teenager group (11-19 years old). Maternal characteristic and neonatal birth weight were described by age groups (Table 1). Primigravid and anemia found during antenatal care (ANC) were more frequent among teenagers, while gestational age at delivery was significantly higher in AMA women group. In addition, birth weight of neonates from teenage mothers was significantly lower than neonates born to AMA mother 3000 (650-3850) vs 3200 (500-4280).

Table 1. Maternal Characteristics and Neonatal Birth Weight during 5-Year Period (2014-2018)

\begin{tabular}{lccc}
\hline \multicolumn{1}{c}{ Maternal Characteristics } & Teenage $(\mathbf{n}=\mathbf{5 4 3})$ & AMA $(\mathbf{n = 3 7 2 2})$ & p-value \\
\hline Maternal age (year) & $18(11-19)$ & $28(20-34)$ & $<0.001$ \\
Gestational age (weeks) & $34(23-42)$ & $38(23-43)$ & $<0.001$ \\
Educational background & $185(34.0 \%)$ & $3152(84.7 \%)$ & $<0.001$ \\
$\quad>9$ years study & & & \\
Occupation & $383(70.5 \%)$ & $1062(28.5 \%)$ & N/A \\
$\quad$ Housewife & $102(18.8 \%)$ & $1566(42.1 \%)$ & \\
$\quad$ Labor & $493(90.8 \%)$ & $1531(41.1 \%)$ & $<0.001$ \\
Primigravid & $3000(650-3850)$ & $3200(500-4280)$ & $<0.001$ \\
Birth weight $(g)^{*}$ & $166(30.6 \%)$ & $872(23.4 \%)$ & $<0.001$ \\
Anemia during ANC & & & \\
\hline
\end{tabular}

*Variables assessed with Mann-Whitney test and expressed as median (range)

All examined variables show significant difference.

During the 5-year period, it was found that the highest pregnancy rate was $28.8 \%$ in 2014 and the lowest pregnancy rate was $15.1 \%$ in 2018 (Table 2). Anemia at labor and PROM were more prevalent among teenage mothers $(p<0.05)$. Neonates with LBW was higher in teenagers compared to AMA women $(43.7 \%$ vs $29.7 \%, p<0.001)$. Teenage mothers give more preterm births compared to AMA women ( $60.4 \%$ vs $40.1 \%)$. On the contrary, neonates with SGA and IUGR were more prevalent in AMA mothers, $4.4 \%$ vs $3.3 \%$ and $10.4 \%$ vs $7.9 \%$, respectively (Table 3 ).

Table 2. The Number of Pregnancies in 5 Year in RSCM

\begin{tabular}{ccc}
\hline Year & $\mathbf{n}$ & $\%$ \\
\hline 2014 & 1228 & 28.8 \\
2015 & 881 & 20.7 \\
2016 & 809 & 19 \\
2017 & 701 & 16.4 \\
2018 & 646 & 15.1 \\
\hline
\end{tabular}


Table 3. The Obstetrical Complications of The Teenage and AMA

\begin{tabular}{lccccc}
\hline \multicolumn{1}{c}{ Complication } & $\begin{array}{c}\text { Teenage } \\
(\mathbf{n = 5 4 3 )}\end{array}$ & $\begin{array}{c}\text { AMA } \\
(\mathbf{n = 3 7 2 2})\end{array}$ & p-Value & OR & 95\% Cl \\
\hline Obstetrical Complication & & & & & \\
$\quad$ Anemia at labor & $95(17.5 \%)$ & $461(12.4 \%)$ & 0.001 & 1.5 & $1.178-1.911$ \\
Preeclampsia & $40(7.4 \%)$ & $641(17.2 \%)$ & $<0.001$ & 0.38 & $0.274-0.533$ \\
Eclampsia & $6(1.1 \%)$ & $80(2.1 \%)$ & 0.106 & 0.5 & $0.221-1.172$ \\
Postpartum hemorrhage & $5(0.9 \%)$ & $52(1.4 \%)$ & 0.367 & 0.65 & $0.261-1.649$ \\
PROM & $205(37.8 \%)$ & $1187(31.9 \%)$ & 0.006 & 1.29 & $1.075-1.561$ \\
Induction of Labor & $17(5.1 \%)$ & $117(8.1 \%)$ & 0.71 & 0.62 & $0.367-1.046$ \\
CS delivery & $210(40.8 \%)$ & $2240(63.3 \%)$ & $<0.001$ & 0.40 & $0.331-0.483$ \\
Instrumental delivery (vacuum or forceps) & $11(3.5 \%)$ & $64(4.7 \%)$ & 0.349 & 0.73 & $0.382-1.407$ \\
Perinatal outcome & & & & 0.739 & $0.451-1.213$ \\
SGA & $18(3.3 \%)$ & $165(4.4 \%)$ & 0.230 & 0.739 \\
Stillbirth & $19(3.5 \%)$ & $186(5 \%)$ & 0.127 & 0.689 & $0.426-1.115$ \\
IUGR & $43(7.9 \%)$ & $387(10.4 \%)$ & 0.075 & 0.741 & $0.533-1.030$ \\
Preterm birth & $328(60.4 \%)$ & $1493(40.1 \%)$ & $<0.001$ & 2.278 & $1.895-2.738$ \\
LBW & $238(43.7 \%)$ & $1106(29.7 \%)$ & $<0.001$ & 1.846 & $1.536-2.217$ \\
$5^{\text {th }}$ min APGAR score $<7$ & $53(9.8 \%)$ & $370(9.9 \%)$ & 0.896 & 0.98 & $0.724-1.327$ \\
\hline
\end{tabular}

${ }^{*}$ All variables were assessed with chi-square test.

The teenage pregnancies were more likely to present along with preterm birth $(\mathrm{OR} 2.047,95 \% \mathrm{Cl}$ 1.660-2.524, $p<0.001$ ), anemia at labor (OR 1.433, $95 \% \mathrm{Cl} 1.113-1.843, \mathrm{p}<0.001)$ and LBW (OR 1.520, $95 \% \mathrm{Cl} 1.229-1.879, \mathrm{p}<0.001)$, compared to AMA pregnancies.

\section{Discussion}

In Indonesia, the number of teenagers who have given births accounts for $10 \%$ of all total births. ${ }^{1}$ Studies demonstrated that teenage pregnancy is already a huge problem with many complications. ${ }^{2-5}$ We found the percentage of anemia at labor, PROM, preterm birth and LBW were significantly higher among teenagers compared to AMA women. The higher incidence of LBW among teenagers in our study was supported by Karai et al. ${ }^{6}$ Other studies also found that young maternal age was a risk factor of LBW. ${ }^{7-10} \mathrm{~A}$ large population-based study by Wang et $\mathrm{al}^{11}$ revealed that maternal hypertension and fruit intake $\geq 300 \mathrm{~g}$ per day during the first trimester were risk factors for LBW; however, maternal BMI $\geq 24 \mathrm{~kg} /$ $\mathrm{m}^{2}$ prior to delivery and gestation $\geq 37$ weeks were protective factors for LBW. ${ }^{11}$ Our study showed that preterm birth was also more prevalent in young pregnancies..$^{7-9}$ Maternal hypertension, eating twice a day and food with a lot of MSG and salt were among the risk factors for preterm birth. ${ }^{11}$

We obtained higher incidence of anemia at labor in the teenagers group compared to AMA women. Studies in developing countries showed that anemia was a public health problem among pregnant teenagers. ${ }^{12-15}$ Maria et al ${ }^{10}$ revealed that preterm births, gestational age at birth $<37$ weeks and stillbirth were more prevalent in non-treated anemia, indicating that anemia was a risk factor for further maternal and neonatal complications. A previous large retrospective study demonstrated that teenage pregnancy was associated with anemia during delivery; however, anemia that was previously detected during antenatal period was not associated with teenage pregnancy, suggesting the possibility that the actual incidence of anemia during ANC in its study population was higher than the results.

Teenage pregnancies have a significantly higher incidence of PROM. One previous retrospective study demonstrated $27.3 \%$ rate of PROM among teenage pregnancies in Indonesia tertiary hospital. Our results were contradicting the results reported by previous studies conducted in the United States and Mexico which observed that preeclampsia and eclampsia were more prevalent in teenage pregnancies. ${ }^{14,15}$ However, a large population-based study involving 8,514 primiparous in France support to our results, we established that the incidence of preeclampsia/eclampsia could actually be higher in adult pregnancies. ${ }^{16}$ Further study revealed that teenage pregnancy and BMI were associated preeclampsia/eclampsia, whereas extremely obese teenagers were almost 